\title{
Kompulsif Satın Alma Davranışı Üzerinde Bedavanın Gücü ${ }^{a}$
}

\author{
Asena Gizem Yiğitt ${ }^{\mathrm{b}, \mathrm{c}}$
}

\section{Özet}

Rasyonel birey varsayımı altında tüketici davranış modelleri, bireylerin, fizyolojik veya psikolojik gerginliklerin azaltılması veya ortadan kaldırılması için ihtiyaç duyulan ürünleri satın aldığını savunmaktadır. Ancak bireylerin karar aşamasında birden fazla uyarıcıya maruz kalması, duygusal ve dürtüsel değişkenlerin varlığı ile bireyler her zaman doğru hesaplanabilir ve rasyonel kararlar alamamaktadrır. Ayrıca tüketim kültüründe meydana gelen değişmeler beraberinde anormal tüketim davranışlarını da getirmektedir. Bu davranışlardan biri olan kompulsif satın alma davranışı çalışmanın temelini oluşturmaktadır.

Bu çalışmada amaç, çevrimiçi alışveriş esnasında kompulsif satın alma düzeyi ile satın alma niyeti arasındaki ilişkinin kargo seçenekleri karşısında değişip değişmediği araştırılmasıdır. Bu amaçla, çalışmanın örneklemi, $\mathrm{Z}$ kuşağına mensup bireylerden oluşmaktadır. Kompulsif Satın Alma ve Satın Alma Niyeti Ölçeklerinden faydalanılarak hazırlanan anketler 128 kişiye uygulanmıştır. Yapılan Fark ve Korelasyon Testleri sonucuna göre bedava kargo seçeneğinde kompulsif satın alma eğilimi ile satın alma niyeti arasında pozitif yönlü düşük bir ilişki; ücretli kargo seçneğinde ise istatistiksel olarak anlamlı olmayan negatif yönlü bir ilişki bulunmaktadır.
Anahtar Kelimeler

Kompulsif Satın Alma

Bedava Kargo

Satın Alma Niyeti

Tüketim Teorisi

Makale Hakkında

Geliş Tarihi: 03.02.2021

Kabul Tarihi: 21.06.2021

Doi: 10.18026/cbayarsos.874134

\section{The Power of Free Over Compulsive Purchasing Behavior}

\begin{abstract}
Under the rational individual assumption, consumer behavior models argue that individuals buy the products needed to reduce or eliminate physiological or psychological strains. However, individuals cannot always be calculated correctly and cannot make rational decisions due to the exposure of individuals to more than one stimulus during the decision phase and the presence of emotional and impulsive variables. In addition, changes in consumption culture bring along abnormal consumption behaviors. Compulsive buying, one of these behaviors, forms the basis of the study. The aim of this study is to investigate whether the relationship between compulsive buying level and purchasing intention changes against shipping options during online shopping. For this purpose, the sample of the study consists of individuals from generation $\mathrm{Z}$. The questionnaires prepared by using the Compulsive Buying Scale and Purchase Intention were applied to 128 people. According to the results of the Difference and Correlation Tests, there is a positive low correlation between compulsive buying tendency and purchase intention in the free shipping option; there is a statistically insignificant negative correlation in the paid cargo option.
\end{abstract}

Keywords

Compulsive Buying

Free Shipping

Purchase Intention

Consumption Theory

About Article

Received: 03.02.2021

Accepted: 21.06.2021

Doi: 10.18026/cbayarsos.874134

\footnotetext{
a Çalışma 28 Ekim/1 Kasım 2020 tarihleri arasında düzenlenen VII. Uluslararası Stratejik Araştırmalar Kongresi'nde sözlü olarak sunulmuştur.

b İletişim Yazarı: asenayigit@sdu.edu.tr

c Araştırma Görevlisi, Süleyman Demirel Üniversitesi/Isparta, 0000-0002-9791-2211.
} 


\section{Giriş}

Yarım asır gibi bir zaman diliminde önemli ölçüde yol kat eden teknoloji, günümüzde her alanda kendini göstermektedir. Mekan ve zaman sınırını ortadan kaldırması, tüketicilerin her daim bulundukları yerden daha hılı ve kolay şekilde ürünlere ulaşım imkanının bulunması, ödeme şekillerinde yaşanan dönüşümler tüketim kültürünü de değiştirmeye başlamıştır. Mal ve hizmet çeşitliliğinin artması, firmaların pazarlama stratejilerinin teknolojiye adaptasyonu, yaşam tarzının değişmesi gibi faktörler, bireylerin ihtiyaçları dışında da tüketim yapmasına vesile olmuştur. Bununla birlikte rasyonel birey anlayışının varsaydığı, bireylerin her daim akılcı karar vererek faydalarını maksimize etmeye yönelik ihtiyaçlarının karşılanması durumu günümüzde kendini irrasyonel kararlara bırakmıştır. Bu kararlar beraberinde anormal tüketim davranışlarını da getirmiştir.

Tüketici araştırmaları, 1980'lerin ortasından bu yana anormal tüketim davranışlarını anlamaya ve açıklamaya yönelmiştir. Bu davranışlardan biri kompulsif satın alma davranışıdır. Dürtüsel satın alma davranışlarından biri olan bu davranış, litratürde kimi araştırmacılar tarafından bağımlılık veya davranış olarak değerlendirilirken kimi araştırmacılar tarafından da hastalık olarak tanımlanmıştır. Dürtüsel satın almayı, dürtüsel olmayan satın almadan ayıran temel özellikler Rook ve Hoch (1987: 191)'a göre şu şekildedir: (a) dürtüsel satın alma daha heyecan verici, ani gelişen ve aciliyeti olan bir satın alma türü olmasına rağmen sıradan bir satın alma daha sakin yapılmaktadır. (b) Dürtüsel satın almada bir ürünü seçmekten ziyade kapmak daha olası bir davranıştır. (c) Dürtüsel satın alma davranışı, tüketicinin davranış akışını bozma eğilimindeyken, sıradan bir satın alma, kişinin normal rutininin bir parçasıdır. (d) Dürtüsel satın alma mantıklı olmaktan çok duygusaldır, dürtüsel olmayan satın alma ise mantıkla ilişkilidir. (e) Normal bir satın alma davranışına kıyasla dürtüsel olarak satın alma davranışında bireyin satın kontrolden çıkmış şekilde hissetme olasılı̆̆ 1 daha yüksektir. Sonrasındaki çalışmalarda dürtüsel satın alma davranışlarının kumar ve alkol bağımlılı̆̆ı, aşırı temizlik hastalığı, aşırı yeme bozukluğu, cinsel dürtüsellik gibi bağımlılıklarla ilişkili olduğu tespit edilmiştir (Rook, 1987: 195). Kompulsif satın alma davranışı ise ilk olarak 1987 yılında yapılan çalışmada tanımlanarak literatüre girmiştir (Faber, O'Guinn ve Krych 1987). Kompulsif tüketim olarak da ele alınan bu satın alma davranışının dürtüsel satın almadan ayıran en önemli unsur, ürün ediniminden ziyade sürece odaklanmasıdır (Hock ve Loewenstein, 1991). Sonuçları bakımından bakıldığında ise kompulsif tüketim yapan bireyler maddi ve manevi daha büyük sıkıntı içinde almaktadırlar. Çünkü dürtüsel tüketim hayat rutinin bir parçası olarak görülebilmektedir (Christenson vd., 1994). Ekonomik ve toplumsal bir problem olarak görülen kompulsif satın alma davranışı, bugün hemen her ülkenin sorunlarından biri halini almıştır. Yapılan çalışmalar, bu aşırı tüketim davranışının toplum içindeki payını açıklamaya ve yarattığı negatif sonuçlardan dolayı karşılaşılan sorunlara değinmektedir (McElroy, Satlin, Pope, Keck ve Hudson, 1991; Koran, Faber, Aboujaoude, Large ve Serpe 2006; Mueller, Mitchell, Crosby, Gefeller, Faber, Martin, Bleich, Glaesmer, Exner ve Zwaan, 2010). Tüketiciler, aşırı tüketim davranışının getirdiğin zararlar konusunda ne kadar bilinçlendirilmeye çalışılsa da, israfa giden tüketim davranışı hala yaygın olarak görülmektedir (Allwood, Ashby, Gutowski ve Worrell, 2013). Ayrıca bu tüketim davranışları, hem çevreyi hem de toplumu tahrip etmekte, bireysel ve toplusal refahı düşürmektedir (Pereira Heath ve Chatzidakis, 2012). Ancak bununla birlikte firma/üreticilerin uyguladığı satış stratejileri, piyasa mekanizması sonucu, daha çok tüketimi teşvik etmektedir. Fiyat promosyonları, ürün promosyonları, kargo seçenekleri ve ücretsiz iadeler tüketiciler açısından kayıp algısını azaltarak tüketime teşvik 
eden araçlardandır (Madhavaram ve Laverie, 2004). Her ne kadar bu promosyonlar ile dürtüsel satın alma davranışı arasındaki ilişkilere yoğunlaşan çalışmalar olsa da (Zhou ve Gu, 2015; Tang ve Hao, 2017; Qaisar, Sial ve Rathour, 2018; Fook ve McNeill, 2020) kompulsif satın alma ilişkisine değinen çalışma sayısı oldukça azdır. Özellikle son zamanda yükselen çevrimiçi alışverişte kargo stratejilerine dayanan çalışma yok denecek düzeydedir. Bu amaçla çalışmada ücretli ve ücretsiz kargo seçeneklerinin kompulsif satın alma eğilimi üzerindeki etkisi incelenmiştir. Böylelikle hem pazarlama ve tüketim literatürüne katkı sağlaması hem de satış konusunda toplumsal bilincin sağlanması beklenmektedir.

\section{Kompulsif Satın Alma Davranışı}

Kompulsiyon olgusuyla ilgili olarak ilk yayın Esquirol (1838) tarafından yapılmış olmasına rağmen bununla ilgili tanımı oluşturan Schneider (1925)dır (Carr, 1974). Kompulsif satın alma olgusu ise, Kraepelin (1915) ve Bleuler (1924) tarafından kavramsal bir tanım kazanmış olsa da (Black, 2007), bu kavrama ait bilimsel bir tanımın net bir çerçevede sunulması Faber, O'Guinn ve Krych tarfından 1987 yılında yapılan çalışmaya dayanmaktadır. Olumsuz duygular neticesinde ortaya çıkan, kronik olarak tekrarlanan, bağımlılık kategorisinde yer alan kompulsif satın alma davranışı (O'Guinn ve Faber, 1989) bireyi ve ailesini hem ekonomik hem de toplumsal olarak etkileyen bir dürtü kontrol bozukluğudur. Diğer bir deyişle, bireyin olumsuz durumlara dürtüsel olarak cevap verişi olmakla beraber, yarattı̆̆ mali sıkıntı sonucunda pişmanlıkla sonuçlanmaktadır. Çünkü birey bu davranışla birlikte bir ürün edinme çabasının haricinde, satın alma sürecinin yarattığı hazla ilgilenmektedir. Kompulsif satın alma davranışının ortaya çıkmasındaki en önemli sebepler özsaygının düşük olması, fiziksel görünümdeki bozukluklar, kaygı bozuklukları, olumsuz duygulardan kaçış ve dürtü bozukluğu gelmektedir. Bu duygular sonucunda aşırı tüketime yönelen bireyin yaşadığı mali ve sosyal problemler ise bireyi major depresyon gibi önemli hastalıklara itmektedir (Krueger, 1988; Edwards, 1993; Yurchisin ve Johnson, 2004). Her ne kadar bu davranış bozukluğunun tedavisi için bir çok çalışma yapılmış olsa da, araştırmacılar net bir görüş birliğine sahip değildir. Ülkeden ülkeye farklılık gösterebilen bu davranışın küresel toplum içindeki yaygınlığ 1 1,1 ile \%16 arasında olduğu bilinmektedir (Lejoyeux, Ades, Tassain ve Solomon, 1996; Koran vd., 2006). Yaygınlık çalışmalarına bakıldığında Faber ve O'Guinn ABD'deki yaygınlık oranını \%5,9 olarak tespit ederken Dittmar vd. (1995) Birleşik Krallık'taki kompulsif tüketim yaygınlığını \%10 olarak tespt etmişlerdir. Kanada'da yapılan bir başka araştırmada ünivesite öğrenciler arasındaki yaygınlık oranı \%12 olarak tespit edilirken (Hassay ve Smith, 1996); Lejoyeux vd. (2011) bu oranı \%11 olarak tahmin etmiştir.

Kompulsif satın alma davranışını etkileyen değişkenlere odaklanıldığında, kaygı bozukluğu, matreyalizm, dürtüsellik, depresyon gibi kişisel değişkenlerin dışında; yaş, cinsiyet, gelir, aile ile ilgili faktörler, kültürel faktörler gibi değişkenlerin de önemli rol oynadığı görülmektedir (Rindfleisch, Burroughs ve Denton, 1997; Türkçapar, 2004; Rose, 2007; Eroğlu, 2016). Ek olarak, yapılan çalışmalar, bu davranışın erkeklere nazaran kadınlarda daha fazla görülmekte olduğunu göstermektedir (Park ve Burns, 2005; Dittmar, 2005). Bu açılardan bakıldığında bu davranışın sadece psikoloji değil aynı zamanda ekonomi ve tüketici davranışı bilimlerinin ortak ilgi alanına girdiği belirtilmektedir (Dittmar, Beattie, Friee, 1995). Sonuçları bakımından ise uzun ve kısa dönemli olmak üzere iki kısımda incelenmektedir. Alışveriş sırasında hissedilen haz duygusu, kaygı, gerginlik gibi duygu durumlardan kısa süreli uzaklaşma ve gerginlik hissinin azaltılması kısa dönemli sonuçları göstermektedir. Ancak bunun yanında 
pişmanlık, depresyon, finansal problemler, düşük öz saygı gibi durumlar da uzun vadeli etkilerdendir (Dittmar, 2005; Korur ve Kimzan, 2016).

Günümüz dünyasında değişen yaşam şartlarına bağlı olarak, önemli bir zaman kısıtı altında olan bireyler daha hızlı ve pratik tüketimi tercih etmektedirler. Bu anlamda çevrimiçi alışveriş platformlarında da hızlı bir yükseliş görülmektedir. Ancak aynı zamanda internetin doğası kompulsif satın alma alışkanlığını tetikleyebilmektedir (Kukar-Kinney, Ridgway ve Monroe, 2009). Çevrimiçi alışveriş, ürün çeşitliliğinin fazla olması, daha uyarıcı ve heyecan verici bir satın alma deneyimi sunması, mekan ve zaman kısıtı tanımaması gibi özellikleri sayesinde kompulsif alıcıların gözünde olumlu duygular elde etmenin bir yolu olarak yer edinmektedir (McAlister ve Pessemier 1982). İnternetin bulunduğu her yerde, kompulsif tüketim yapan bireylerin, dürtü atağı geldiği her an gözlerden uzak bir şekilde kolayca alışveriş yapabilmeyi sağlamaktadır. Bu yönüyle, internet, kompulsif satın alma davranışına sahip bireylerin, dürtülerini ertelemeden tatmin edebilmelerine imkan vermektedir (Zeren ve Gökdağlı, 2017). Kredi kartı kullanım oralarının da kompulsif tüketimi destekleyici unsurlardan biri olduğunu varsaymaktadır (Ünsalver, 2011). Nitekim bu varsayımının doğruluğunu kanıtlayan çalışmalar da mevcuttur (Kaderli, Armağan ve Küçükkambak, 2017; Aslanoğlu ve Korga, 2017).

\section{Literatür}

Kompulsif satın alma davranışının dürtüsel bir bozukluk olması ve kişinin olumsuz duygularını bastırmak için araç olarak da kullanılabilmesi araştırmacıları bu alana yönelttiği gibi birçok satış stratejisi de bu alan üzerine kurulmaya başlanmıştır. Günümüz tüketim kültürünün bir ögesi olan promosyonların kullanımı bireyleri daha fazla tüketim yapmaya zorlamaktadır. Ayrıca bireylerin kendilerini tanımlamak için ürünleri kullanmaları (Krueger 1988), satın alma bağımlılıklarını, kumar, içki, uyuşturucu kullanımı gibi diğer bağımlılıklardan daha ciddi bir duruma getirmektedir (Friese 2000). Özellikle çevrimiçi (online) alışverişte birden fazla teşvik edici değişkenin ortama eklenmesi, kişilerin tüketim kararlarında çoğu zaman dürtüsel davranmalarına sebebiyet vermektedir (Madhavaram ve Laverie, 2004). Çünkü çevrimiçi alışveriş kullanıcılarının hızlı şekilde artış göstermesi, firmalar için potansiyel bir pazar sağlamaktadır. Bununla beraber, eğilimi fark eden şirketler, daha fazla müşteri kazanmak ve mevcut satışları artırmak için de çeşitli çevrimiçi alışveriş promosyon stratejileri kullanmaktadır $(\mathrm{Tu}, \mathrm{Wu}$, Jean ve Huang, 2017). Buradan hareketle promosyonlara dayalı satın alma faaliyetlerinin daha yakından incelenmesinde fayda vardır. Her ne kadar literatürde dürtüsel satın alımların fiyat, bedava ürün, kargo seçenekleri gibi promosyonel stratejilerle ilişkileri nadir olarak ele alınmış olsa da bu değişkenlerin kompulsif satın alma davranışı ile olan ilişkisine değinen çok az sayıda kaynağa rastlanmıştır. Bu anlamda satış promosyonları gibi daha spesifik alanlar ile kompulsif alışveriş davranışını ölçmeye odaklanan bir araştırma eksikliği vardır (Roberts ve Manolis, 2000).

Alandaki çalışmalar daha yüksek dürtüsel satın alma eğilimine sahip alıcıların, düşük dürtüsel alıcılara kıyasla, reklamlar, görsel öğeler ve promosyon hediyeler gibi dış uyaranlara karşı çok daha duyarlı olduğunu ortaya koymaktadır (Youn ve Faber, 2000). Promosyonların dürtüsel satın alma üzerindeki etkisine odaklanan Tu, Wu, Jean ve Huang (2017), 20-30 yaş arasında toplamda 330 kişiden toplamış oldukları verileri regresyon analizi ile incelemiştir. Promosyonları dört boyutlu olarak ele alan araştırmacıların analiz sonuçlarına göre, fiyat indirimlerinin dürtüsel satın alma üzerinde en büyük etkiye sahip değişken olduğunu bulgulamışlardır. "Hızlı satış" promosyonunun ikinci, "daha çok satın al daha çok tasarruf et" 
promosyonunun üçüncü ve indirim kuponlarının dördüncü sırada etkiye sahip olduğu tespit edilmiştir. Ayrıca sonuçlar, çevrimiçi promosyonların çevrimiçi dürtüsel satın alma davranışı üzerinde önemli ölçüde olumlu etkileri olduğunu göstermiştir. Dürtüsel satın alma davranışı ile promosyonların arasındaki ilişkiyi açıklamaya çalışan çalışmalardan bir diğeri ise Pakistan' da yapılmıştır. Toplam 550 kişiden oluşan örneklemden toplanan verilen regresyon analizine tabi tutulmuştur. Çalışmanın bulguları, bir alana bir bedava promosyonu, örnek ve fiyat indirimi gibi promosyon uygulamaları ile dürtüsel satın alma davranışı arasında pozitif ve anlamlı bir ilişkiye sahip olduğunu göstermekte iken, kupon uygulamaları ile bu davranış arasında bir ilişkiye rastlanmamıştır (Qaisar, Sial ve Rathour, 2018).

Vicdan ve Sun (2008) çalışmalarında ise kompulsif satın alma davranışına değinmişlerdir. Çalışma, satış promosyonlarının internetteki kompulsif alıcılar üzerindeki rolünü açıklamayı ve kompulsif satın alma ile çevrimiçi alışveriş eğilimi arasındaki ilişkiyi incelemeyi amaçlamaktadır. Bu amaç doğrultusunda yaşları 21 ile 30 arasında değişen 200 öğrenciden, kompulsif satın alma ölçeği ve satış promosyonları eğilim ölçeği ile hazırlanan anketler ile veriler toplanmıştır. Yapısal Eşitlik Modeli kullanılarak yapılan analizin sonuçları kompulsif alıcıların satış promosyonlarına daha yatkın olduğunu göstermektedir. Dahası, kompulsif alıcıların satış promosyonlarına eğilimi, çevrimiçi satış promosyonlarına maruz kalma olasılığını arttırmaktadır. Ayrıca çevrimiçi satış promosyonlarına maruz kalma sıklığı, satış promosyonu eğilimi ile çevrimiçi satış promosyonlarının tüketicinin kullanımı arasındaki ilişkiye de aracılık etmektedir. Armağan ve Temel (2018) tarafından yapılan bir diğer çalışma ise benzer şekilde, çevrimiçi alışveriş tutumunun kompulsif satın alma davranışı üzerinde etkili olduğunu bulgulamıştır. Satış stratejilerinin yanı sıra internet bağımlılığı olan bireylerin de daha fazla kompulsif satın alma davranışı sergilediklerine dair tespitler de mevcuttur (Yakın ve Aytekin, 2019). Bu değişkenlerin yanı sıra çevrimiçi kompulsif tüketim davranışın etkileyen unsurlardan kültürel farklılıkların ele alındığı baka bir çalışmada ise Türkiye ve ABD örneklemi ile yapılmıştır. İstanbul'dan (663), Washington D.C'den (597) toplanan verilere göre yapılan analizler sonucunda kültürler arası farkın çevrimiçi kompulsif tüketim davranışını etkilediğine yönelik sonuçlara ulaşılmıştır (Benli ve Ferman, 2019).

Kompulsif satın alma davranışı ile satış promosyonları arasındaki ilişkiyi incelemeyi amaçlayan bir diğer çalışma ise Wang ve Jing (2015) tarafından yapılmıştır. Dört faklı markaya ait promosyonlar ( $\mathrm{X}$ kadar alışveriş sonrasında $\mathrm{Y}$ kadar indirim çeki veya $\mathrm{Z}$ markasında \%30 indirim) düzenlenmiş ve anket/gözlem yollarıyl bilgiler alınmıştır. Toplamda 162 kişiden toplanan veriler lojistik regresyon analizine tabi tutulmuştur. Analiz sonuçları, indirim ve hediye gibi seçeneklerin kompulsif satın alımları tetiklediğini göstermiştir.

\section{Veri ve Yöntem}

Çevrimiçi alışverişte kullanılan satış stratejilerinden biri olan kargo seçenekleri ile kompulsif satın alma davranışı ile satın alma niyeti arasındaki ilişkiyi açıklamak amacıyla yapılan bu çalışmada kullanılan veriler kolayda örnekleme yöntemiyle çevrimiçi anket yardımıyla toplanmıştır. Temel beklenti kompulsif tüketim eğilimi ile satın alma niyeti arasında, kargonun bedava olduğu durumda pozitif yönlü bir ilişkinin gözlenmesidir. Bunun için öncelikle "kargo bedava" seçeneğine karşılık "ürün bedeli + kargo ücreti” seçeneğinin kişilerin satın alma niyetlerini değiştirip değiştirmediği araştırılmıştır. Çalışmada kullanılan ürün, son zamanlarda zorunluluk haline gelen tıbbi bir maskedir. Sonrasında ise kompulsif satın alma düzeyi ile satın alma niyeti arasındaki ilişkinin kargo seçenekleri karşısında değişip değişmediği araştırılmıştır. Bu amaçlarla her iki grupta 64'er kişi olmak üzere toplam 128 
kişiden veri toplanmıştır. Burada örneklem sayısı belirlenirken, son 10 yıldır sosyal ve davranış bilimleri dahil olmak üzere biyoloji, genetik, tıbbi araştırmalar, yer bilimleri, ekoloji ve istatistiksel testleri rutin olarak uygulayan diğer birçok disiplinde kullanılan GPower güç analizinden yararlanılmıştır (Sheppard, 1999; Busbey, 1999; Akkad vd., 2006; Baeza ve Stotz, 2003; Faul vd., 2007). Gözlem sayısı güç analizi ile orta etki düzeyinde (d=0.5), \%5 hata payı ve $\% 80$ güç düzeyinde GPower programı ile belirlenmiştir. Diğer analizler SPSS 23 paket programıla gerçekleştirilmiştir. Kompulsif satın alma eğilimini ölçmek için Edwards (1993)'ın geliştirdiği ölçekten yararlanılmıştır. Satın alma niyetinin ölçülmesi için ise Wang, Li, Barnes ve Ahn (2012)'ın üç soruluk satın alma niyeti ölçeği kullanılmıştır. Kompulsif satın alma düzeyinin kuşaklar arasında fark olabileceği için, örneklemin homojenliği bakımından, anketler Z kuşağındaki bireylere kolayda örnekleme yöntemiyle uygulanmıştır. Anketlerde deney ve kontrol grubu olmak üzere iki farklı gruba bir ürün gösterilmiş ve bu ürün kontrol grubuna ücretli kargo seçeneği ile sunulurken deney grubuna bedava kargo seçeneği ile sunulmuştur. Ancak her iki grupta da kargo seçenekleri değişmesine rağmen gösterilen ürünün toplamda fiyatı aynıdır. Yani "kargo bedava" ibaresiyle gösterilen fotoğrafta ürünün fiyatı 35,99 TL iken, "kargo ücreti" ibaresinin gösterildiği fotoğrafta 28,99 TL+ 7 TL (kargo bedeli) şeklinde gösterilmiştir. Her iki grup için de alınmak istenen ürün için toplamda ödenecek tutar 35,99 TL'ye denk gelmektedir. Sonuç olarak hipotezler aşağıdaki gibi oluşturulmuştur:

H1: Satın alma niyeti kargo seçeneğine göre farklılaşmaktadır.

H2: Kompulsif satın alma düzeyi ile satın alma niyeti arasındaki ilişki kargo seçeneklerine göre değişmektedir.

İlk hipotez fark testi ile ikinci hipotez ise korelasyon analizi ile sınanmıştır. Analizlere geçilmeden önce satın alma niyeti ve kompulsif satın almaya ilişkin ölçeklerden elde edilen skorların normal dağılıma uyup uymadıkları tespiti yapılmıştır.

Tablo 1. Ölçek Skorlarına İlişkin Çarpıklık ve Basıklık Değerleri

\begin{tabular}{ccccccc}
\hline Gruplar & Ölçek Skorları & $\mathbf{N}$ & $\overline{\mathbf{x}}$ & Ss. & Çarpıklık (S) & Basıklık (K) \\
\hline \multirow{2}{*}{ Kargo bedava } & SAN $^{*}$ & 64 & 3.135 & 1.078 & -0.071 & -0.943 \\
& KSA $^{* *}$ & 64 & 2.960 & 0.655 & 0.339 & -0.409 \\
+ Kargo ücreti & SAN & 64 & 2.755 & 1.041 & 0.213 & -0.898 \\
& KSA & 64 & 2.817 & 0.681 & 0.323 & -0.123 \\
\hline
\end{tabular}

* SAN: Satın Alma Niyeti ** KSA: Kompulsif Satın Alma

Tablo 1'den görüldüğü üzere ölçek skorlarının çarpıklık ve basıklık değerleri -1.96 ile +1.96 arasında bulunmaktadır. Dolayısıyla skorların normal dağılıma uyduğu kabul edilebilmektedir (Güriş, S. ve Astar, M., 2014). Normal dağılıma uygunluğun görülmesiyle birlikte ilk hipotez (H1) Bağımsız Örneklem t Testiyle sınanmıştır ve Tablo 2' de testin sonuçları gösterilmektedir. 
Tablo 2. Satın Alma Niyetinin Kargo Seçeneğine Göre Farklılaşıp Farklılaşmadığına İlişkin Bağımsız Örneklem t Testi Sonuçları

\begin{tabular}{ccccccccc}
\hline $\begin{array}{c}\text { Bağımlı } \\
\text { Değişken }\end{array}$ & Gruplar & N & $\bar{X}$ & ss & F & P & t & P \\
\hline $\begin{array}{c}\text { Satın Alma } \\
\text { Niyeti }\end{array}$ & Kargo bedava & 64 & 3.135 & 1.078 & 0.012 & 0.914 & 2.029 & $0.045^{*}$ \\
\hline
\end{tabular}

*5 düzeyinde anlamlı.

Tablo 2'deki sonuçlar incelendiğinde satın alma niyetinin kargo seçeneğine göre anlamlı şekilde farklılaştığ 1 görülmektedir. Beklentiyle uyumlu olarak kargo bedava seçeneği satın alma niyetini kargonun ücretli olduğu seçeneğe göre yükseltmiştir. Kargo bedava seçeneğinde satın alma niyeti ortalama 3.135 seviyesinde ve kararsız olarak ifade edilen 3 değerinin üzerindedir. Buna karşılık ücretli kargo seçeneğinde ortalama satın alma niyeti 2.755 düzeyindedir ve kararsızlığ 1 ifade eden 3 değerinin altındadır. Bu sonuçla birlikte birinci hipotez (H1) desteklenmektedir.

Birinci hipotez böylelikle desteklenmesiyle birlikt ikinci hipotezin sınamasına (H2) geçilmiştir. İkinci hipotezin sınanabilmesi için Pearson korelasyon analizinden faydalanılmıştır. Sonuçlar Tablo 3'te sunulmuştur.

Tablo 3. Satın Alma Niyeti ile Kompulsif Satın alma Eğilimi Arasındaki İlişkiye Yönelik Pearson Korelasyon Analizi Sonuçları

\begin{tabular}{|c|c|}
\hline \multicolumn{2}{|c|}{ Kargo Bedava } \\
\hline & Kompulsif Satın Alma \\
\hline Satın Alma Niyeti & $0.391^{*}$ \\
\hline \multicolumn{2}{|c|}{ Kargo Ücretli } \\
\hline & Kompulsif Satın Alma \\
\hline Satın Alma Niyeti & -0.104 \\
\hline \% \%1 düzeyinde anlaml
\end{tabular}

Korelasyon analizi sonuçlarına göre kargonun bedava olarak gösterildiği seçenekte kompulsif satın alma eğilimi ile satın alma niyeti arasında pozitif yönlü düşük bir ilişki bulunmaktadır. "Kargo bedava" seçeneğinin söz konusu olduğu durumda kompulsif satın alma eğilimi yükseldikçe satın alma niyeti de düşük oranda da olsa yükselmektedir. Dolayısıyla ikinci hipotez de desteklenmiştir. "Ücretli kargo" seçeneğinde ise bu ilişki istatistiksel olarak anlamlı değildir. Ancak belki küçük ve önemli bir işaret olarak yorumlanabilecek bir sonuç bulunmaktadır. "Ücretli kargo" gösterimi olduğu zaman kompulsif satın alma eğilimi ile satın alma niyeti arasında çok çok düşük negatif yönlü bir ilişki olabileceği değerlendirilebilir. Bu sonuç, başka bir çalışmada sınanabilecek bir yorum olmakla birlikte kargonun ücretli olduğu durumlarda kompulsif satın alma eğilimi yükseldikçe satın alma niyeti düşüyor olabilir.

\section{Tartışma ve Sonuç}

Takıntılı tüketim davranışı olarak da bilinen kompulsif satın alma davranışının, daha önce yapılan çalışmalarda da fiyat indirimi, bir alana bir bedava kampanyaları gibi promosyonlardan etkilendiği bulgulanmıştır. Bireylerin nazarında yarattığı "en karlı alışveriş" algısından dolayı günümüzde firmalar satış stratejilerini bunun gibi pomosyonların 
üzerine oturtmaktadır. Özellikle çevrimiçi alışveriş esnasında, bireylerin ürünleri yakından inceleyememesi, dokunamaması gibi durumlar risk algısı yaratırken promosyonlar bu risk algısını azaltmaktadır. Kargo seçeneğinin ücetsiz olması da kişiye kazanç algısı yaratmaktadır. Bazı firmalar ise belli bir tutar üstündeki alışverişler için kargo gönderim ücretini almamaktadır. Bu durum dahi kişilerin alışveriş sepetini belirlenen tutara kadar doldurmasıyla sonuçlanabilmektedir.

Literatürde kompulsif satın alma davranışı ile promosyon seçenekleri arasındaki ilişkiyi araştıran çalışma sayısının çok az olması, bu çalışma konusunda yol gösterici olmuştur. Toplamda 128 kişilik iki guba yapılan anketler, ürün görselleri aynı olmakla beraber, kargo seçeneklerinde farklılık verilmiştir. Bir gruba ürün fiyatı 35,99 TL ve kargo bedava şeklinde beyan edilirken, diğer gruba 28,99 TL+ 7 TL kargo ücreti şeklinde gösterilmiştir. Daha sonra her iki gruba da satın alma niyeti ölçeği ve kompulsif satın alma ölçeğinin sorularıyla hazırlnan anketler çevrimiçi olarak yaptırılmıştır. Elde edilen bulgular beklentiyle uyumlu olarak, her iki grupta da ödeme tutarının aynı olmasına rağmen, kargo ücretinin olmadığ grubun ürün satın alma niyeti, diğer gruba oranla daha yüksek olmuştur. Ayrıca yine satın alma niyeti ile kompulsif satın alma eğilimi arasındaki ilişki bedava kargo seçeneğinde istatistiksel olarak anlamlı ve pozitif iken, kargonun ücretli olarak gösterildiği grupta bu iki değişken arasındaki ilişki istatistiksel olarak anlamsız ancak negatif yönde olduğu tespit edilmiştir. Buna göre kompulsif satın alma eğilimi yükseldikçe, ürünü satın alma eğilimi artmaktadır. Buradan hareketle kargo seçeneğinin bedava olması kompulsif satın alma yapan tüketicileri, kompulsif satın alma yapmayan tüketicilere nazaran daha fazla cezbetmektedir. Dolayısıyla satın alma için katlanılacak toplam maliyet içinde bedava unsurların olması kompulsif satın alma eğilimi yüksek olanların satın alma eğilimlerini de güçlendirmektedir.

Tüketicilerin satın alma sonrasında karşılaştıkları maliyetler, bireyler için kaybı temsil etmektedir. Ancak kargo seçeneğinin bedava olmasının bu kaybın yarattığ 1 "acıyı" hafiflettiği düşünülmektedir. Bireylerin kayıptan kaçınma davranşının bir göstergesi olarak kargo seçeneğinin bedava olduğu yerde satın alma eylemine yönelmesi kaçınılmaz bir sonuç olarak karşımıza çıkmaktadır. Kompulsif satın alma davranışı gösteren bireylerde ise bu düşünce daha fazla yer bulmaktadır. Çünkü bu davranışa sahip bireyler, satın alma davranışı sonrasında bir pişmanlık ile karşılaşmaktadırlar. Dolayısıyla bedava seçeneği onlar için pişmanlığı mali açıdan hafifletmenin bir yolu olarak da görülebilmektedir. Bu yüzden tüketicilerin, satın alma kararlarını verirken, bedavanın cazibesine kapılmadan, iyi bir araştırmayla ürünleri alması önerilmektedir. Önemli olan hususun ürün edinim mi yoksa promosyon mu olduğu gözden kaçırılmalıdır. Böylelikle israfa yönelik tüketimin de mali açıdan yaşanan kaybın da önüne geçilebilir. Konu, yöntemleri ve örneklemi bakımından genişletilerek ele alınabilir. Bu açıdan yapılması muhtemel yeni çalışmalara da ışık tutacaktır. 


\section{Kaynakça}

Akkad, D. A., Jagiello, P., Szyld, P., Goedde, R., Wieczorek, S., Gross, W. L. ve Epplen, J. T. (2006). Promoter polymorphism in the MHC class II transactivator gene is not associated with susceptibility for selected autoimmune diseases in German patient groups, International Journal of Immunogenetics 33, 59-61

Allwood, J.M., Ashby, M.F., Gutowski, T.G., Worrell, E. (2013). Material efficiency: providing material services with less material production, Phil Trans R Soc A 371: 20120496.

Armağan, E. ve Temel, E. (2018). Türkiye' de Online Kompulsif Alışveriş Davranışı Üzerine Ampirik Bir Çalışma, Dokuz Eylül Üniversitesi Sosyal Bilimler Enstitüsü Dergisi, 20(4), 621-653.

Aslanoğlu, S. ve Korga, S. (2017). Kredi Kartı Kullanımı ve Kompulsif Satın Alma: Kırıkkale İlinde Bir Uygulama, İşletme Araştırmaları Dergisi, 9(1), 148-165.

Black, D.W. (2007). A Review of Compulsive Buying Disorder, World Psychiatry, 6, 14-18.

Baeza, J. A., \& Stotz, W. (2003). Host-use and selection of differently colored sea anemones by the symbiotic crab Allopetrolisthes spinifrons, Journal of Experimental Marine Biology and Ecology 284, 25-39.

Benli, B. ve Ferman, M. (2019). The Effect of Cultural Dimensions On Conspicuous Consumption and Online Compulsive Buying Behavior: A Comparative Study Among Turkish and American Consumers, Journal of Management, Marketing and Logistics, 6(2), 103127.

Busbey, A. B. I. (1999). Macintosh shareware/freeware earthscience software, Computers and Geosciences 25, 335-340.

Carr, A. T. (1974). Compulsive Neurosis: A Review of the Literature, Psychological Bulletin, 81(5), 311-318.

Christenson, G., Faber, R. J., Zwaan, M., Raymond, N.C., Specker, S.M., Ekern, M.D., Mackenzie, T.B., Crosby, R.D., Crow, S.J. ve Eckert, E. D. (1994). Compulsive buying: Descriptive characteristics and psychiatric comorbidity, The Journal of Clinical Psychiatry, 55(1), $5-11$

Dittmar H., Beattie J. ve Friese S. (1995). Gender identity and material symbols: objects and decision considerations in impulse purchases, J Economic Psychol, 15, 391-511.

Dittmar, H. (2005). A New Look at "Compulsive Buying": Self-Discrepancies and Materialistic Values As Predictors of Compulsive Buying Tendency, Journal of Social and Clinical Psychology, 24(6), 832-859.

Edwards, E.A. (1993). Development of a new scale for measuring compulsive buying behaviour, Financial Counseling and Planning 4, 67-85.

Eroğlu, F. (2016). Kompulsif Satın Alma: Kişisel Faktörler, Postmodern Tüketim Şekilleri ve Reklama Karşı Tutumun Rolüne Yönelik Bir Araştırma, Balıkesir Üniversitesi Sosyal Bilimler Enstitüsü Dergisi, 19(35), 253-282.

Faber, R. J., O'Guinn, T.C. ve Krych, R. (1987), "Compulsive Consumption," in Advances in Consumer Research, Vol. 14, ed. M. Wallendorf and P. Anderson, Provo, UT: Association for Consumer Research, 132-135. 
Faul, F., Erdfelder, E., Lang, A.-G. ve Buchner, A. (2007). G*Power 3: A flexible statistical power analysis program for the social, behavioral, and biomedical sciences, Behavior Research Methods 39, 175-191

Fook, L. A. ve McNeill, L. (2020). Click to Buy: The Impact of Retail Credit on OverConsumption in the Online Environment, Sustainability 12, 7322, doi:10.3390/su12187322.

Friese, S. (2000). A Self-Concept and Identity in a Consumer Society: Aspects of Symbolic Product Meaning, Germany: Marburg, Tectum.

Güriş, S. ve Astar, M., (2014). Bilimsel Araştırmalarda SPSS ile İstatistik, İstanbul: DER Yayınları.

Hassay, D.N. ve Smith, M.C. (1996). Compulsive Buying: An Examination of the Consumption Motive, Journal of Psychology and Marketing, 13(8), 741-752.

Hoch, S.J. ve Loewenstein, G.F. (1991). Time-inconsistent Preferences and Consumer SelfControl, Journal of Consumer Research 17, 492-507.

Kaderli, Y., Armağan, E. A. ve Küçükkambak, S.E. (2017). Y Kuşağının Kompulsif Satın Alma Davranışına Etki Eden Faktörler Üzerine Bir Araştırma, İstanbul Üniversitesi İşletme Fakültesi Dergisi, 46 (2), 188-210.

Koran, L.M., Faber, R.J., Aboujaoude, E., Large, M.D. ve Serpe, R.T., (2006). Estimated prevalence of compulsive buying behavior in the United States, The American Journal of Psychiatry 163, 1806-1812.

Korur, M.G. ve Kimzan, H.S. (2016). Kompulsif Satın Alma Eğilimi ve Alışveriş Sonrası Pişmanlık İlişkisinde Kontrolsüz Kredi Kartı Kullanımın Rolü: AVM Müşterileri Üzerine Bir Araştırma, Tüketici ve Tüketim Araştırmaları Dergisi, 8(1), 43-71

Krueger, D.W. (1988). On Compulsive Shopping and Spending: A Psychodynamic Inquiry, American Journal Of Psychotherapy, 62(4), 574-584.

Kukar-Kinney, M., Ridgway, N. M. ve Monroe, K. B. (2009). The Relationship Between Consumers' Tendecies to Buy Compulsively and Their Motivations to Shop and Buy on The Internet, Journal of Retailing, 85(3), 298-307.

Lejoyeux, M., Ades, J., Tassain, V. ve Solomon, J. (1996). Phenomenology and psychopathology of unctrolled buying, Am J Psychiatry, 153(12), 1524-1529.

Madhavaram, S. R. ve Laverie, D. A. (2004). Exploring impulse purchasing on the internet. in NA-Advances in Consumer Research 31, eds. Kahn and Luce, Valdosta, GA: Association for Consumer Research, 59-66.

McAlister, L. ve Pessemier, E. (1982). Variety-Seeking Behavior: An Interdisciplinary Review, Journal of Consumer Research, 9(3), 311-322.

McElroy, S.L., Satlin, A., Pope, H.G., Keck, P.E., and Hudson, J.I. (1991). Treatment of Compulsive Shopping with Antidepressants A Report of Three Cases, Annals of Clinical Psychiatry 3, 199-204.

Mueller, A., Mitchell, J. E., Crosby, R. D., Gefeller, O., Faber, R. J., Martin, A., Bleich, S., Glaesmer, H., Exner, C. ve Zwaan, M. (2010). Estimated prevalence of compulsive buying in 
Germany and its association with sociodemographic characteristics and depressive symptoms, Psychiatry Research, 180 (2-3), 137-142.

Park, H. ve Burns, L.D.(2005). Fashion Orientation, Credit Card Use, and Compulsive Buying, Journal of Consumer Marketing, 22(3), 135-141.

Pereira Heath, M.T. ve Chatzidakis, A. (2012). 'Blame it on marketing': Consumers' views on unsustainable consumption, Int. J. Consum. Stud. 36, 656-667.

Rindflesich, A., Burroughs, J.E. ve Denton, F. (1997). Family Structure, Materialism and Compulsive Consumption, Journal of Consumer Research 23, 312-325.

Roberts, J. A. ve Manolis, C. (2000). Baby boomers and busters: An exploratory investigation of attitudes toward marketing, advertising and consumerism, Journal of Consumer Marketing, 17 (6), 481-499.

Rook, D. W. (1987). The Buying Impulse, Journal of Consumer Research, 14 (September), 189199.

Rose, P. (2007). Mediators of the Association between Narcissism and Compulsive Buying: The Roles of Materialism and Impulse Control, Psychology of Addictive Behaviors, Journal of The Society of Psychologists in Addictive Behaviors, 21(4), 576-581.

Sheppard, C. (1999). How large should my sample be? Some quick guides to sample size and the power of tests, Marine Pollution Bulletin 38, 439-447.

Tang, T. ve Hao, L. (2017). Research on the Influence of Price Promotion on Consumer Purchase Decision under Network Environment, Advances in Social Science, Education and Humanities Research 168, 220-224.

Tu, C. K., Wu, K.W., Jean, C. ve Huang, Y. (2017). The Impact Of Online Promotions On Online Impuls ive Buying Behavior: Mediating Effects Of Perceived Value, Positive Emotion, And Moderating Effects Of Online Reviews , Economics \& Management Innovations, 1(1), 280282.

Türkçapar, H. (2004). Anksiyete Bozukluğu ve Depresyonun Tanısal İlişkileri, Klinik Psikiyatri 4, 12-16.

Qaisar, A., Sial, M.A. ve Rathour, K. (2018). Understanding Impulse Buying Behaviour of Customers Through The Lens of Different Marketing Related Promotional Practices, Journal of the Punjab University Historical Society,31 (1), 23-35.

Vicdan, H. ve Sun, J. (2008). Towards a framework for understanding compulsive buyers online : exploring the effects of online sales promotions, http://www.swdsi.org/swdsi08/paper/SWDSI\%20Proceedings\%20Paper\%20S155.pdf, $\quad$ E.T.: 15.10.2020

Wang, M. ve Jing, X. (2015). The Study of Sales Promotion and Compulsive Buying, Journal of Management and Strategy, 6(2), 105-108

Wang, C.L, Li, D., Barnes, B.R. ve Ahn, J. (2012). Country Image, Product Image and Consumer Purchase Intention: Evidence from an Emerging Economy, International Business Review 21, 1041-1051 
Yakın, V. ve Aytekin, P. (2019). İnternet Bağımlılığının Online Kompulsif ve Online Anlık Satın Alma Davranışlarına Etkisi, İşletme Fakültesi Dergisi, 20(1), 199-222.

Yurchisin, J. ve Johnson, K. K. P. (2004). Compulsive Buying Behavior and Its Relationship to Perceived Social Status Associated with Buying, Materialism, Self-Esteem, and ApparelProduct Involvement, Family and Consumer Sciences Research Journal, 32(3), 291-314.

Youn, S. ve Faber, R. J. (2000). Impulse buying: Its relation to personality traits and cues, Advances in Consumer Research, 27, 179-185.

Zeren, D. ve Gökdağlı, N. (2017). Satın Alma Motivasyonları: Tüketicilerin Sanal Kompülsif Davranışları Üzerine Bir Araştırma, Dumlupınar Üniversitesi Sosyal Bilimler Dergisi Pazarlama Kongresi Özel Sayısı, 41-58

Zhou, H. ve Gu, Z. (2015). The Effect of Different Price Presentations on Consumer Impulse Buying Behavior: The Role of Anticipated Regret, American Journal of Industrial and Business Management 5, 27-36 